\title{
Synthesis and application of new iminopyridine ligands in the enantioselective palladium-catalyzed allylic alkylation
}

\author{
Maurizio Solinas $^{\mathrm{a}}$, Barbara Sechi ${ }^{\mathrm{a}}$, Giorgio Chelucci ${ }^{\mathrm{b}, *}$, Salvatore Baldino $^{\mathrm{b}}$, \\ José R. Pedro ${ }^{\mathrm{C}}$, Gonzalo Blay ${ }^{\mathrm{c}}$ \\ a CNR, Istituto di Chimica Biomolecolare UOS Sassari, Traversa La Crucca 3, I-07100 Sassari, Italy \\ b Dipartimento di Agraria, Università di Sassari, Viale Italia 39, 07100 Sassari, Italy \\ c Departament de Química Orgànica, Facultat de Química, Universitat de València, C/Dr. Moliner 50, E-46100 Burjassot (València), Spain
}

\section{A R T I C L E I N F O}

\section{Article history:}

Received 17 December 2013

Received in revised form 2 January 2014

Accepted 3 January 2014

Available online 26 January 2014

\section{Keywords:}

Iminopyridine ligands

Enantioselective catalysis

Allylic substitution

Palladium catalysis

\begin{abstract}
A B S T R A C T
A variety of iminopyridines were obtained by condensation of chiral amines with pyridine-2carboxaldehyde and quinoline-8-carbaldehyde, or of aminoalkylpyridine derivatives with chiral ketones. These ligands were assessed in the enantioselective palladium catalyzed allylic substitution of 1,3-diphenylprop-2-enyl acetate with dimethyl malonate affording the product dimethyl 1,3diphenylprop-2-enylmalonate in good yields and moderate enantioselectivities (up to 62\% ee). Catalytic activity and enantioselectivity were found to be highly dependent upon the steric properties of the ligands. The best enantioselectivity ( $62 \%$ ee) was obtained by an iminopyridine based on a camphane skeleton.
\end{abstract}

(C) 2014 Elsevier B.V. All rights reserved.

\section{Introduction}

Transition-metal-catalyzed asymmetric allylic substitutions [1], particularly those employing palladium- [2], copper- [3], iridium[4] or molybdenum-complexes [5] have become some of the most powerful tools for asymmetric $\mathrm{C}-\mathrm{C}$ and $\mathrm{C}-$ heteroatom bond formation, finding wide application in the synthesis of valuable molecules and complex natural products [6].

In the past few decades, a plethora of efficient chiral ligands has been developed for this asymmetric process. Most of them are mixed bidentate donor ligands with $P-P$ or $P-N$ chelating mode [1-6], although several interesting examples of $N, N$-chelating ligands such as diamines [7], pyridine-based ligands (2,2'-bipyridines, 1,10-phenanthrolines, pyridyl amines, pyridyl oxazolines, etc.) [8] and oxazoline-containing ligands [9] have also proven their efficiency.

Notwithstanding chiral $\mathrm{N}, \mathrm{N}$-ligands based on imino and pyridine moieties have become a large and important topic in asymmetric synthesis, they have been barely applied in allylic substitution reactions [10]. Hoveyda and co-workers developed readily modular peptide-based iminopyridine ligands 1 (Fig. 1), which led to an interesting level of regio- and enantioselectivity in the Cu-catalyzed allylic substitution of cinnamyl phosphates

\footnotetext{
* Corresponding author. Tel.: +39 079 229539; fax: +39 079229559

E-mail address: chelucci@uniss.it (G. Chelucci).
}

with diethylzinc [11]. Lacour and co-workers reported that the combination of unsymmetrical iminopyridine ligands L2 (Fig. 1) and the ruthenium complex $\left[\mathrm{CpRu}(\mathrm{MeCN})_{3}\right] \mathrm{PF}_{6}$ afforded highly regio- and enantioselective Carroll rearrangements, this being the first example of Ru-catalyzed asymmetric $\mathrm{C}-\mathrm{C}$ bond-forming allylic substitution [12]. Finally, the tridentate PNN ligands L3a-c (Fig. 1) were compared by Zheng and co-workers in the palladiumcatalyzed allylic alkylation of 1,3-diphenylprop-2-enyl pivalate and cyclohexenyl acetate with dimethyl malonate in the presence of BSA-KOAc, but as a result, it was found that the ligand L3a with a 2-pyridine $\mathrm{N}$-atom surprisingly showed no activity, thus indicating that this type of ligand works well only in a $P-N$ chelating fashion [13].

We have recently reported the synthesis and application in the copper(II)-catalyzed Henry reaction of iminopyridine ligands obtained by condensation of chiral amines with pyridine-2-carboxaldehyde L2 or (5S,7R)-6,6-dimethyl-2phenyl-5,7-methanoquinolin-8(5H)-one $\mathbf{L 4}$ [14], or by reaction of aminoalkylpyridines with naturally occurring chiral ketones L5 [15]. Since, as mentioned-above, these type of chiral ligands have been never applied in Pd-catalyzed allylic substitutions, in line with our ongoing efforts to explore highly enantioselective reactions using simple and cheap chiral catalytic systems [16], we have investigated the potential of this type of chiral ligands in asymmetric Pd-catalyzed allylic substitutions. Herein we report the comparative results obtained in the Pd-catalyzed allylic alkylation of 1,3-diphenylprop-2-enyl acetate with dimethyl malonate 


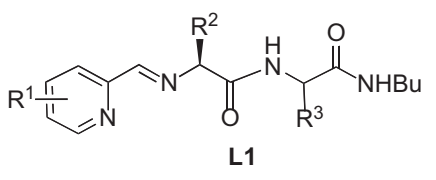<smiles>[R]N=C1C[C@@H]2C[C@H](c3nc(-c4ccccc4)ccc32)C1(C)C</smiles>
L4

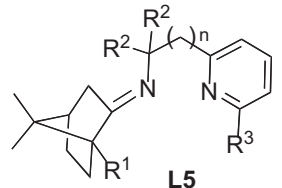<smiles>[R]c1cc([R])nc(/C=N/C([R])C)c1</smiles>

L2

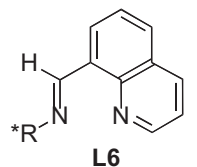

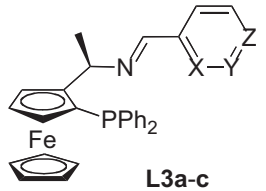

a: $X=N, Y=Z=C H$

b: $Y=N, X=Z=C H$

c: $Z=N, X=Y=C H$

Fig. 1. Ligands applied in allylic substitution reactions.

using the known iminopyridines of the type $\mathbf{L} 2$ and $\mathbf{L 5}$, and the new iminopyridines L6 (Fig. 1). It should be noted that all the examined ligands share the imino and pyridine moieties, but differ from their chelating properties. In fact, both ligands $\mathbf{L 2}$ and $\mathbf{L 5}(n=0)$ form a five-membered chelate ring with palladium, but differ from the orientation of the $\mathrm{N}=\mathrm{C}$ double bond, which is directed forward the pyridine ring in ligands $\mathbf{L 2}$ and in the opposite side in ligands $\mathbf{L 5}$. On the other hand, ligands $\mathbf{L 5}(n=1)$ and $\mathbf{L 6}$ form a six-membered chelate ring in a rather rigid structure.

\section{Experimental}

\subsection{General remarks}

Ligand syntheses were carried out under nitrogen atmosphere in oven-dried glassware with magnetic stirring, while catalytic allylic alkylation reactions were performed without air or moisture exclusion. Unless otherwise noted, all materials were obtained from commercial suppliers and were used without further purification. All solvents were HPLC grade. THF was distilled from sodium-benzophenone ketyl and degassed thoroughly with dry nitrogen directly before use. Unless otherwise noted, organic extracts were dried with $\mathrm{Na}_{2} \mathrm{SO}_{4}$, filtered through a fritted glass funnel, and concentrated with a rotary evaporator (20-30 mmHg). Flash chromatography was performed with silica gel (200-300 mesh) using the mobile phase indicated. Melting points are collected using a BÜCHI B-540 and are uncorrected. ${ }^{1} \mathrm{H}$ and ${ }^{13} \mathrm{C}$ NMR spectra were recorded on a Varian Mercury $\left({ }^{1} \mathrm{H}\right.$ 400.1 MHz, ${ }^{13} \mathrm{C} 100.6 \mathrm{MHz}$ ) with tetramethylsilane (TMS) as reference. Chemical shifts $(\delta)$ are reported in ppm and multiplicity is indicated as follow: $\mathrm{s}=$ singlet, $\mathrm{d}=$ doublet, $\mathrm{t}=$ triplet, $\mathrm{q}=$ quartet, $\mathrm{m}=$ multiplet, $\mathrm{bs}=$ broad signal. Coupling constants $(J)$ are indicated in hertz. Ligands $\mathbf{2 a}-\mathbf{e}$ [15], 2f [17], and 4a,c-g [14] were prepared according to reported procedures.

\subsection{1. (1R,4R)-1,7,7-Trimethylbicyclo[2.2.1]heptan-2-} ylidene)quinolin-8-amine

(2f)

This compound was prepared according to our procedure [17]: $\operatorname{mp~} 110-112^{\circ} \mathrm{C} ;[\alpha]_{\mathrm{D}}{ }^{25}=-5.8\left(\right.$ c $\left.1.0, \mathrm{CHCl}_{3}\right) ;{ }^{1} \mathrm{H}$ NMR $(400.1 \mathrm{MHz}$, $\left.\mathrm{CDCl}_{3}\right): \delta=8.10(\mathrm{~d}, J=4.4 \mathrm{~Hz}, 1 \mathrm{H}, \mathrm{ArH}), 8.08(\mathrm{~d}, J=8.4 \mathrm{~Hz}, 1 \mathrm{H}, \mathrm{ArH})$, 7.50-7.41 (m, 2H, ArH), 7.32 (dd, $J=8.8,4.4 \mathrm{~Hz}, 1 \mathrm{H}, \mathrm{ArH}), 7.06$ (d, $J=6.8 \mathrm{~Hz}, 1 \mathrm{H}, \mathrm{ArH}), 2.06(\mathrm{dt}, J=17.2,4.0 \mathrm{~Hz}, 1 H), 1.92-1.74(\mathrm{~m}, 4 H)$, $1.50(\mathrm{~d}, J=17.2 \mathrm{~Hz}, 1 \mathrm{H}), 1.27-122(\mathrm{~m}, 1 \mathrm{H})$, overlapped with 1.25 (s, $3 \mathrm{H}, \mathrm{CH} 3), 1.04$ (s, 3H, CH3), 1.00 (s, 3H, $\left.\mathrm{CH}_{3}\right) .{ }^{13} \mathrm{C}$ NMR $(100.6 \mathrm{MHz}$, $\left.\mathrm{CDCl}_{3}\right): \delta=185.2,148.8,148.2,139.3,134.8,128.0,125.6,121.3$, 119.8, 116.9, 53.3, 46.6, 42.8, 36.1, 31.3, 26.4, 18.8, 18.2, 10.3. Anal. Calcd. for $\mathrm{C}_{19} \mathrm{H}_{22} \mathrm{~N}_{2}$ : C, 81.97; $\mathrm{H}, 7.97 ; \mathrm{N}, 10.06$. Found: C, 82.33; $\mathrm{H}$, $7.85 ; \mathrm{N}, 10.01$.

\subsection{General procedure for the synthesis of imines $\mathbf{5 a - d , f , g}$}

The proper amine $(1.8 \mathrm{mmol})$ was added dropwise to a stirred mixture of quinoline- 8 -carbaldehyde $(0.28 \mathrm{~g}, 1.8 \mathrm{mmol})$ and anhydrous $\mathrm{K}_{2} \mathrm{CO}_{3}(0.5 \mathrm{~g})$ in anhydrous diethyl ether $(10 \mathrm{~mL})$. The resulting mixture was stirred at room temperature overnight and then filtered. The organic phase was evaporated and the residue was purified by flash chromatography eluting with petroleum ether $/$ EtOAc $=9: 1$.

\subsection{1. (S,E)-N-(1-Phenylethyl)-1-(quinolin-8-yl)methanimine}

(5a)

Yield 82\%; Pale yellow oil; $[\alpha]_{\mathrm{D}}{ }^{25}=-94.5\left(\mathrm{c} 0.5, \mathrm{CHCl}_{3}\right) ;{ }^{1} \mathrm{H} \mathrm{NMR}$ $\left(400.1 \mathrm{MHz}, \mathrm{CDCl}_{3}\right): \delta=9.78(\mathrm{~s}, 1 \mathrm{H}, \mathrm{NCH}), 8.96(\mathrm{dd}, J=4.2,1.8 \mathrm{~Hz}, 1 \mathrm{H}$, ArH), 8.52 (dd, $J=7.3,1.5 \mathrm{~Hz}, 1 \mathrm{H}, \mathrm{ArH}), 8.19(\mathrm{dd}, J=8.3,1.8 \mathrm{~Hz}, 1 \mathrm{H}$, ArH), 7.89 (dd, $J=8.1,1.5 \mathrm{~Hz}, 1 \mathrm{H}, \mathrm{ArH}), 7.60$ (t, $J=7.6 \mathrm{~Hz}, 1 \mathrm{H}, \mathrm{ArH}$ ), $7.51(\mathrm{~d}, J=7.5 \mathrm{~Hz}, 2 \mathrm{H}, \mathrm{ArH}), 7.44(\mathrm{dd}, J=8.3,4.2 \mathrm{~Hz}, 1 \mathrm{H}, \mathrm{ArH}), 7.35(\mathrm{t}$, $J=7.5 \mathrm{~Hz}, 2 \mathrm{H}, \mathrm{ArH}), 7.24(\mathrm{t}, J=7.5 \mathrm{~Hz}, 1 \mathrm{H}, \mathrm{ArH}), 4.77(\mathrm{q}, J=6.6 \mathrm{~Hz}, 1 \mathrm{H})$, $1.67\left(\mathrm{~d}, J=6.6 \mathrm{~Hz}, 3 \mathrm{H}, \mathrm{CH}_{3}\right) ;{ }^{13} \mathrm{C} \mathrm{NMR}\left(100.6 \mathrm{MHz} \mathrm{CDCl}_{3}\right): \delta=157.3$, $150.1,146.8,145.6,136.4,133.3,128.5(2 \mathrm{C}), 128.3,127.9,126.9(2 \mathrm{C})$, 126.8, 126.6, 126.4, 121.3, 70.4, 25.0; Anal. Calcd. for $\mathrm{C}_{18} \mathrm{H}_{16} \mathrm{~N}_{2}$ : C, 83.04; H, 6.19; N, 10.76. Found: C, 83.22; H, 6.20; N, 10.53 .

\subsection{2. (R,E)-N-(1-(Naphthalen-1-yl)ethyl)-1-(quinolin-8-} $y$ l)methanimine

(5b)

Yield 84\%; white solid $\mathrm{mp} 92-94^{\circ} \mathrm{C}$; $[\alpha]_{\mathrm{D}}^{25}=-97.6$ (c 1.1 $\left.\mathrm{CHCl}_{3}\right) ;{ }^{1} \mathrm{H} \mathrm{NMR}\left(400.1 \mathrm{MHz}, \mathrm{CDCl}_{3}\right): \delta=9.89(\mathrm{~s}, 1 \mathrm{H}, \mathrm{NCH}), 8.96(\mathrm{dd}$, $J=4.2,1.7 \mathrm{~Hz}, 1 \mathrm{H}, \mathrm{ArH}), 8.59$ (dd, $J=7.3,1.5 \mathrm{~Hz}, 1 \mathrm{H}, \operatorname{ArH}), 8.36$ (d, $J=8.4 \mathrm{~Hz}, 1 \mathrm{H}, \mathrm{ArH}), 8.19(\mathrm{dd}, J=8.3,1.7 \mathrm{~Hz}, 1 \mathrm{H}, \operatorname{ArH}), 7.94-7.87(\mathrm{~m}$, $3 H, A r H), 7.76(\mathrm{~d}, J=8.2 \mathrm{~Hz}, 1 H, \operatorname{ArH}), 7.64(\mathrm{t}, J=7.1 \mathrm{~Hz}, 1 \mathrm{H}, \mathrm{ArH})$, 7.57-7.43 (m, $4 H, A r H), 5.58(\mathrm{q}, J=6.6 \mathrm{~Hz}, 1 \mathrm{H}), 1.81(\mathrm{~d}, J=6.6 \mathrm{~Hz}, 3 \mathrm{H}$, $\left.\mathrm{CH}_{3}\right) ;{ }^{13} \mathrm{C} \mathrm{NMR}\left(100.6 \mathrm{MHz}, \mathrm{CDCl}_{3}\right): \delta=157.5,149.9,146.6,141.6$, 136.3, 133.9, 133.2, 130.6, 130.3, 128.8, 128.1, 127.7, 127.1, 126.5, 125.7, 125.6, 125.2, 123.9, 123.6, 121.2, 66.3, 24.8; Anal. Calcd. for $\mathrm{C}_{22} \mathrm{H}_{18} \mathrm{~N}_{2}$ : C, 85.13; H, 5.85; N, 9.03. Found: C, 85.65; H, 5.90; N, 9.53 .

\subsection{3.}

(R,E)-N-(1-Cyclohexylethyl)-1-(quinolin-8-yl)methanimine (5c)

Yield 81\%; pale yellow oil; $[\alpha]_{\mathrm{D}}{ }^{25}=-38.0\left(c 1.4, \mathrm{CHCl}_{3}\right) ;{ }^{1} \mathrm{H} \mathrm{NMR}$ $\left(400.1 \mathrm{MHz}, \mathrm{CDCl}_{3}\right): \delta=9.56(\mathrm{~s}, 1 \mathrm{H}, \mathrm{NCH}), 8.96(\mathrm{dd}, J=4.2,1.8 \mathrm{~Hz}$, $1 H, \mathrm{ArH}), 8.44(\mathrm{dd}, J=7.7,1.5 \mathrm{~Hz}, 1 \mathrm{H}, \mathrm{ArH}), 8.16(\mathrm{dd}, J=8.3,1.8 \mathrm{~Hz}$, $1 H, A r H), 7.86(\mathrm{dd}, J=8.1,1.5 \mathrm{~Hz}, 1 \mathrm{H}, \mathrm{ArH}), 7.59(\mathrm{t}, J=7.7 \mathrm{~Hz}, 1 \mathrm{H}$, ArH), 7.43 (dd, $J=8.3,4.2 \mathrm{~Hz}, 1 \mathrm{H}, \mathrm{ArH}$ ), 3.27 (quin, $J=6.5 \mathrm{~Hz}, 1 \mathrm{H}, \mathrm{CH}$ ), 1.89-1.84 (m, 1H), 1.79-1.61 (m, 4H), 1.56-1.54 (m, 1H), 1.29 (d, $\left.J=6.5 \mathrm{~Hz}, 3 \mathrm{H}, \mathrm{CH}_{3}\right)$, overlapped with $1.34-1.12(\mathrm{~m}, 3 \mathrm{H}), 0.98-0.94$ $(\mathrm{m}, 2 \mathrm{H}) ;{ }^{13} \mathrm{CNMR}\left(100.6 \mathrm{MHz}, \mathrm{CDCl}_{3}\right): \delta=156.5,150.7,146.8,136.4$, 133.6, 130.1, 128.4, 127.8, 126.7, 121.3, 72.3, 44.1, 30.2, 30.0, 26.8, 26.6, 26.5, 20.2; Anal. Calcd. for $\mathrm{C}_{18} \mathrm{H}_{22} \mathrm{~N}_{2}$ : C, 81.16; $\mathrm{H}, 8.32 ; \mathrm{N}$, 10.52. Found: C, $81.66 ; \mathrm{H}, 8.55 ; \mathrm{N}, 10.76$. 
2.2.4.

(R,E)-N-(3,3-Dimethylbutan-2-yl)-1-(quinolin-8-yl)methanimine (5d)

Yield 85\%; pale yellow oil; $[\alpha]_{\mathrm{D}}{ }^{25}=-68.1\left(c 1.1, \mathrm{CHCl}_{3}\right) ;{ }^{1} \mathrm{H} \mathrm{NMR}$ $\left(400.1 \mathrm{MHz}, \mathrm{CDCl}_{3}\right): \delta=9.59(\mathrm{~s}, 1 \mathrm{H}, \mathrm{NCH}), 8.97(\mathrm{dd}, J=4.2,1.8 \mathrm{~Hz}$, $1 H, A r H), 8.46$ (dd, $J=7.7,1.5 \mathrm{~Hz}, 1 H, A r H), 8.17$ (dd, $J=8.3,1.8 \mathrm{~Hz}$, $1 H, A r H$ ), 7.87 (dd, $J=7.7,1.5 \mathrm{~Hz}, 1 H, A r H), 7.60(\mathrm{t}, J=7.7 \mathrm{~Hz}, 1 H$, $\operatorname{ArH}$ ), 7.43 (dd, $J=8.3,4.2 \mathrm{~Hz}, 1 \mathrm{H}, \operatorname{ArH}$ ), 3.23 (quin, $J=6.6 \mathrm{~Hz}, 1 H$, $\mathrm{CH}), 1.24\left(\mathrm{~d}, J=6.6 \mathrm{~Hz}, 3 \mathrm{H}, \mathrm{CH}_{3}\right), 0.98(\mathrm{~s}, 9 \mathrm{H}) ;{ }^{13} \mathrm{C} \mathrm{NMR}(100.6 \mathrm{MHz}$, $\left.\mathrm{CDCl}_{3}\right): \delta=156.3,150.1,146.8,136.5,133.7,129.9,128.4,127.8$, 126.7, 121.3, 75.8, 34.6, 26.8 (3 C), 17.6; Anal. Calcd. for $\mathrm{C}_{16} \mathrm{H}_{20} \mathrm{~N}_{2}$ : C, 79.96; H, 8.39; N, 11.66. Found: C, 79.46; H, 8.79; N, 10.86.

\subsection{5. (E)-1-(Quinolin-8-yl)-N-((2S,4R)-1,7,7-}

trimethylbicyclo[2.2.1]heptan-2-yl)methanimine

(5f)

Yield 86\%; white solid mp $126-129^{\circ} \mathrm{C} ;[\alpha]_{\mathrm{D}}{ }^{25}=-5.1$ (c 1.1, $\left.\mathrm{CHCl}_{3}\right) ;{ }^{1} \mathrm{H} \mathrm{NMR}\left(400.1 \mathrm{MHz}, \mathrm{CDCl}_{3}\right): \delta=9.57(\mathrm{~s}, 1 \mathrm{H}, \mathrm{NCH}), 8.97$ (dd, $J=4.2,1.8 \mathrm{~Hz}, 1 \mathrm{H}, \mathrm{ArH}), 8.50$ (dd, $J=7.3,1.4 \mathrm{~Hz}, 1 \mathrm{H}, \mathrm{ArH}$ ), 8.19 (dd, $J=8.3,1.8 \mathrm{~Hz}, 1 \mathrm{H}, \mathrm{ArH}), 7.89(\mathrm{dd}, J=8.1,1.4 \mathrm{~Hz}, 1 \mathrm{H}, \mathrm{ArH}), 7.61(\mathrm{t}$, $J=7.7 \mathrm{~Hz}, 1 \mathrm{H}, \mathrm{ArH}), 7.44$ (dd, $J=8.3,4.2 \mathrm{~Hz}, 1 \mathrm{H}, \mathrm{ArH}), 3.72-3.68(\mathrm{~m}$, $1 H, \mathrm{CH}), 2.37-2.22(\mathrm{~m}, 2 H), 1.87-1.78(\mathrm{~m}, 1 H), 1.75(\mathrm{t}, J=4.4 \mathrm{~Hz}$, $1 H), 1.50-1.44(\mathrm{~m}, 1 H), 1.40(\mathrm{dd}, J=13.0,3.9 \mathrm{~Hz}, 1 H), 1.35-1.27(\mathrm{~m}$, $1 \mathrm{H}), 1.0\left(\mathrm{~s}, 3 \mathrm{H}, \mathrm{CH}_{3}\right), 0.94\left(\mathrm{~s}, 3 \mathrm{H}, \mathrm{CH}_{3}\right), 0.75\left(\mathrm{~s}, 3 \mathrm{H}, \mathrm{CH}_{3}\right) ;{ }^{13} \mathrm{C} \mathrm{NMR}$ $\left(100.6 \mathrm{MHz}, \mathrm{CDCl}_{3}\right): \delta=157.0,150.0,146.8,136.5,133.8,129.9$, 128.4, 127.9, 126.7, 121.3, 76.0, 51.0, 48.6, 45.8, 37.6, 28.8, 28.6, 19.9, 19.0, 13.7; Anal. Calcd. for $\mathrm{C}_{20} \mathrm{H}_{24} \mathrm{~N}_{2}$ : C, 82.15; H, 8.27; N, 9.58. Found: C, 82.51; H, 8.49; N, 9.80.

\subsection{6. (E)-1-(Quinolin-8-yl)-N-((1R,2R,3S,5S)-2,6,6-} trimethylbicyclo[3.1.1]heptan-3-yl)methanimine

(5g)

Yield 83\%; white solid mp 80-81 ${ }^{\circ} \mathrm{C} ;[\alpha]_{\mathrm{D}}{ }^{25}=+8.7\left(c \mathrm{c} 1.0, \mathrm{CHCl}_{3}\right)$; ${ }^{1} \mathrm{H} \mathrm{NMR}\left(400.1 \mathrm{MHz}, \mathrm{CDCl}_{3}\right): \delta=9.52(\mathrm{~s}, 1 \mathrm{H}, \mathrm{NCH}), 8.97$ (dd, $J=4.2$, $1.8 \mathrm{~Hz}, 1 \mathrm{H}, \mathrm{ArH}$ ), 8.48 (dd, $J=7.3,1.4 \mathrm{~Hz}, 1 \mathrm{H}, \mathrm{ArH}), 8.19$ (dd, $J=8.3$, $1.8 \mathrm{~Hz}, 1 \mathrm{H}, \mathrm{ArH}), 7.89$ (dd, $J=8.1,1.4 \mathrm{~Hz}, 1 \mathrm{H}, \mathrm{ArH}), 7.61(\mathrm{t}, J=7.7 \mathrm{~Hz}$, $1 H, \mathrm{ArH}), 7.44$ (dd, $J=8.3,4.2 \mathrm{~Hz}, 1 \mathrm{H}, \mathrm{ArH}), 3.80-3.75(\mathrm{~m}, 1 \mathrm{H}, \mathrm{CH})$, 2.45-2.33 (m, $2 H$ ), 2.25-2.17 ( $\mathrm{m}, 1 H), 2.01-1.98$ ( $\mathrm{m}, 2 H), 1.92-1.89$ $(\mathrm{m}, 1 H), 1.32(\mathrm{~d}, J=9.5 \mathrm{~Hz}, 1 \mathrm{H}), 1.27\left(\mathrm{~s}, 3 \mathrm{H}, \mathrm{CH}_{3}\right), 1.11\left(\mathrm{~s}, 3 \mathrm{H}, \mathrm{CH}_{3}\right)$, $1.06\left(\mathrm{~d}, J=7.4 \mathrm{~Hz}, 3 \mathrm{H}, \mathrm{CH}_{3}\right) ;{ }^{13} \mathrm{C} \mathrm{NMR}\left(100.6 \mathrm{MHz}, \mathrm{CDCl}_{3}\right): \delta=155.7$, 150.1, 146.8, 136.5, 133.6, 130.0, 128.4, 127.9, 126.7, 121.3, 70.6, 47.8, 43.6, 42.0, 39.1, 36.1, 34.3, 28.3, 23.7, 20.0; Anal. Calcd. for $\mathrm{C}_{20} \mathrm{H}_{24} \mathrm{~N}_{2}$ : C, 82.15; H, 8.27; N, 9.58. Found: C, 82.61; H, 8.49; N, 9.86 .

\subsection{General procedure for the enantioselective allylic alkylation reaction}

In a typical procedure a solution of $\left[\mathrm{Pd}\left(\eta^{3}-\mathrm{C}_{3} \mathrm{H}_{5}\right) \mathrm{Cl}\right]_{2}(4 \mathrm{mg}$, $2.5 \mathrm{~mol} \%$ ) and of the appropriate ligand ( $0.04 \mathrm{mmol}, 10 \mathrm{~mol} \%)$ $(\mathrm{L} / \mathrm{Pd}=4 / 1)$ in $\mathrm{CH}_{2} \mathrm{Cl}_{2}(3 \mathrm{~mL})$ was stirred at room temperature for $30 \mathrm{~min}$. Then, 1,3-diphenylprop-2-enyl acetate 6 $(100.9 \mathrm{mg}, 0.4 \mathrm{mmol})$, dimethyl malonate $(159.0 \mathrm{mg}, 1.2 \mathrm{mmol})$, $\mathrm{N}, \mathrm{O}$-bis(trimethylsilyl)acetamide (BSA) $(244.0 \mathrm{mg}, 1.2 \mathrm{mmol})$ and $\mathrm{CH}_{3} \mathrm{COOK}$ (1.4 mg, $0.014 \mathrm{mmol}, 3.5 \mathrm{~mol} \%$ ) were added in sequence. The reaction was monitored by TLC analysis (hexane/diethyl ether $=3: 1$ ). After the proper time (see Table 1 ), the reaction mixture was diluted with ether and washed with an ice-cold saturated $\mathrm{NH}_{4} \mathrm{Cl}$ solution. The organic phase was dried over anhydrous $\mathrm{Na}_{2} \mathrm{SO}_{4}$, and concentrated under reduced pressure. The residue was purified by flash chromatography (hexane/diethyl ether = 3:1) to afford 1,3-diphenylprop-2-enyl malonate 7. The enantiomeric excess was determined by HPLC analysis using a Chiracel OD-H column with hexane/IPA 90:10 as the eluent, $0.5 \mathrm{~mL} / \mathrm{min}$. Retention time: $11.9 \mathrm{~min}$ for the $R$ enantiomer and $12.6 \mathrm{~min}$ for the $S$ enantiomer.
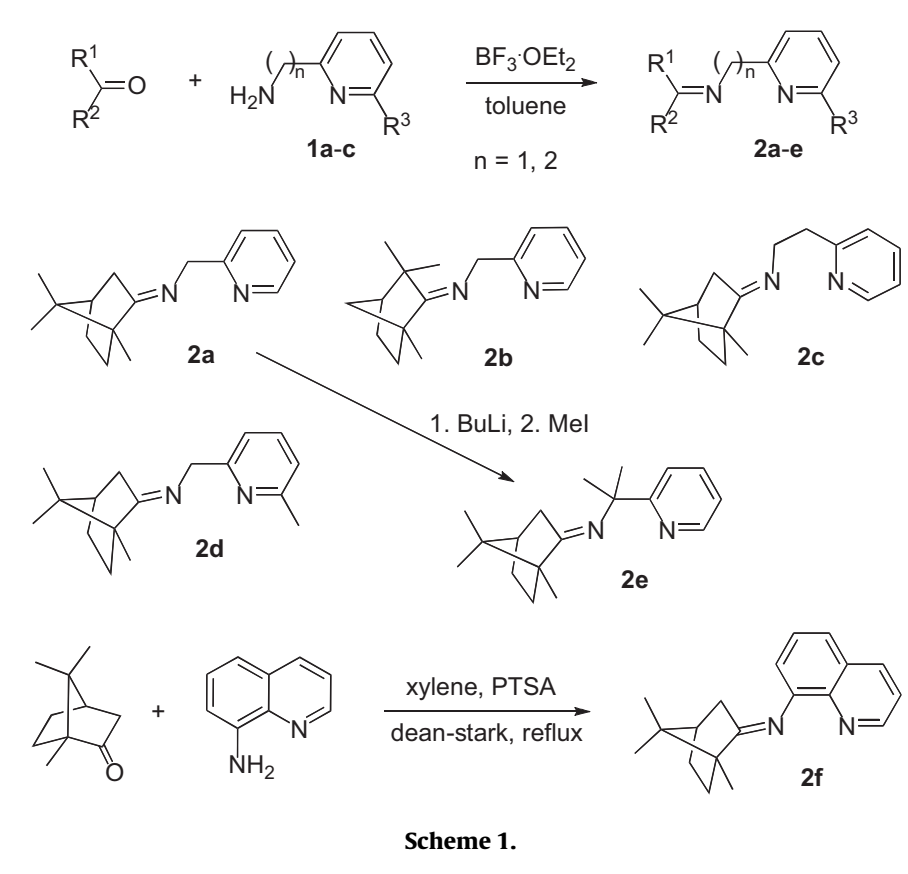

\section{Results and discussion}

\subsection{Synthesis of the ligands}

Iminopyridines 2a-d were easily obtained by condensation of chiral ketones, $(1 R)-(+)$-camphor or $(1 R)$-fenchone, with aminoalkylpyridine derivatives in the presence of a catalytic amount of $\mathrm{BF}_{3} \cdot \mathrm{OEt}_{2}$ (Scheme 1) [15], while aminopyridine 2e was formed by double alkylation with BuLi and MeI of the benzylic position of $\mathbf{2 a}$ [15]. Ligand $\mathbf{2 f}$ was prepared by reaction of 8aminoquinoline with $(1 R)-(+)$-camphor as previously described by us [17], and now full characterized (Scheme 1).

The iminopyridines $\mathbf{4 a}, \mathbf{c}-\mathbf{g}$ were formed in one step by condensation of pyridine-2-carboxaldehyde with the chiral amines $\mathbf{3 a}, \mathbf{c}-\mathbf{g}$ in diethyl ether containing anhydrous $\mathrm{K}_{2} \mathrm{CO}_{3}$ at room temperature (Scheme 2) [13]. Analogously to ligands $\mathbf{4}$, the iminopyridines $\mathbf{5 a}-\mathbf{d}, \mathbf{f}, \mathbf{g}$ were obtained by reaction of quinoline-8-carbaldehyde with the chiral amines 3a-d,f,g (Scheme 2). All ligands $\mathbf{4}$ and $\mathbf{5}$ were obtained as pure $E$ isomers as determined by NOESY NMR spectra.

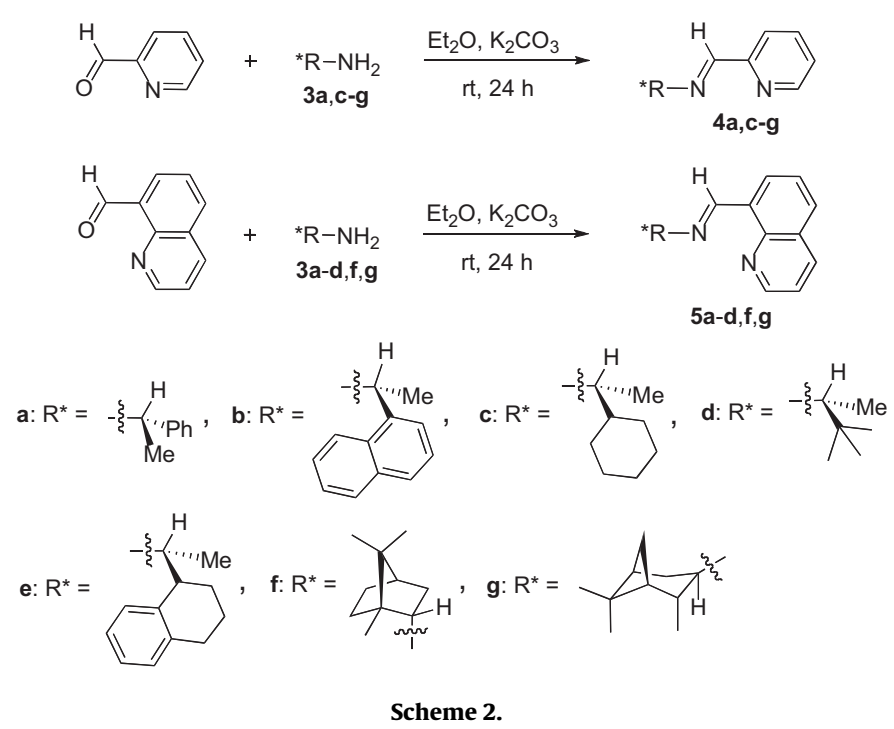


Table 1

Allylic alkylation of 1,3-diphenylprop-2-enyl acetate with dimethyl malonate (Scheme 3). ${ }^{\text {a }}$

\begin{tabular}{|c|c|c|c|c|c|c|}
\hline Entry & Ligand & Time (h) & Conversion (\%) ${ }^{\mathrm{b}}$ & Yield $(\%)^{c}$ & ee $(\%)^{d}$ & Configuration $^{\mathrm{e}}$ \\
\hline 1 & $\mathbf{2 a}$ & 20 & 100 & 91 & 54 & $S$ \\
\hline 2 & $\mathbf{2 b}$ & 20 & 100 & 92 & 38 & $S$ \\
\hline 3 & $2 c$ & 24 & 100 & 88 & 34 & $S$ \\
\hline 4 & $2 d$ & 48 & 100 & 76 & 9 & $S$ \\
\hline 5 & $2 e$ & 24 & 37 & nd & nd & - \\
\hline 6 & $\mathbf{2 e}$ & 72 & 62 & 23 & 62 & $R$ \\
\hline 7 & $2 f$ & 72 & 50 & 30 & 20 & $R$ \\
\hline 8 & $4 a$ & 72 & 7 & nd & nd & - \\
\hline 9 & $4 c$ & 20 & 100 & 98 & 25 & $S$ \\
\hline 10 & 4d & 20 & 100 & 92 & 7 & $R$ \\
\hline 11 & $4 e$ & 20 & 100 & 79 & 44 & $R$ \\
\hline 12 & $4 f$ & 24 & 100 & 87 & 0 & - \\
\hline 13 & $4 \mathrm{~g}$ & 72 & 55 & 52 & 5 & - \\
\hline 14 & $5 a$ & 21 & 100 & 95 & 20 & $S$ \\
\hline 15 & $5 b$ & 72 & 70 & 63 & 18 & $R$ \\
\hline 16 & $5 c$ & 24 & 87 & 87 & 16 & $S$ \\
\hline 17 & $5 d$ & 44 & 95 & 89 & 16 & $S$ \\
\hline 18 & $5 f$ & 72 & 44 & 35 & 9 & $S$ \\
\hline 19 & $5 \mathrm{~g}$ & 24 & 79 & 59 & 5 & $R$ \\
\hline 20 & $5 \mathrm{~g}$ & 72 & 100 & 73 & 5 & $R$ \\
\hline
\end{tabular}

a Reaction conditions: ligand $(0.04 \mathrm{mmol}, 10 \mathrm{~mol} \%),\left[\mathrm{Pd}\left(\eta^{3}-\mathrm{C}_{3} \mathrm{H}_{5}\right) \mathrm{Cl}\right]_{2}(4 \mathrm{mg}, 2.5 \mathrm{~mol} \%), 1,3-$ diphenylprop-2-enyl acetate $(0.4 \mathrm{mmol}), \mathrm{CH} \mathrm{C}_{2}(\mathrm{COOMe}){ }_{2}(1.2 \mathrm{mmol}), \mathrm{N}, \mathrm{O}-$ bis(trimethylsilyl)acetamide (BSA) $(1.2 \mathrm{mmol})$ and $\mathrm{KOAc}(1.4 \mathrm{mg}, 0.014 \mathrm{mmol}, 3.5 \mathrm{~mol} \%)$ in $\mathrm{CH}_{2} \mathrm{Cl}_{2}(3 \mathrm{~mL})$ at room temperature.

$\mathrm{b}$ Determined by ${ }^{1} \mathrm{H}$ NMR of the crude reaction mixture.

c Isolated yields.

d Determined by chiral HPLC (see Section 2 for details).

e The assignment is based on the sign of the optical rotation, see Ref. [20].

\subsection{Palladium-catalyzed asymmetric allylic alkylation}

As a model study of palladium catalyzed allylic substitutions, the iminopyridines were assessed in the alkylation of 1,3diphenylprop-2-enyl acetate $\mathbf{6}$ with dimethyl malonate, following a standard protocol that entails the use of $\left[\mathrm{Pd}\left(\eta^{3}-\mathrm{C}_{3} \mathrm{H}_{5}\right) \mathrm{Cl}_{2}\right.$ as the precatalyst and the generation of the nucleophile by in situ treatment of dimethyl malonate with $\mathrm{N}, \mathrm{O}$-bis(trimethylsilyl)acetamide (BSA) and potassium acetate in a methylene chloride solution at room temperature (Scheme 3) [18].

Starting our investigation, we examined the iminopyridines $\mathbf{2 a}$ and $\mathbf{2 b}$, derived from $(1 R)-(+)$-camphor and (1R)-fenchone, respectively. These ligands gave moderately reactive Pd-catalysts requiring $20 \mathrm{~h}$ at room temperature to convert the starting material 6 to dimethyl 1,3-diphenylprop-2-enylmalonate (S)-7 in 91 and $92 \%$ yield and with 54 and $38 \%$ enantiomeric excess, respectively (Table 1).

The promising result obtained with 2a prompted us to continue this investigation by modifying the ligand framework. The accepted mechanism for palladium catalyzed allylic substitutions, which proceed through a meso $\eta^{3}$-allyl intermediate, foresees that the nucleophile attacks the allylic termini of two alternative diastereomeric $\pi$-allyl palladium complexes, which interconvert through a $\pi-\sigma-\pi$ mechanism and are present at the equilibrium in a different ratio $(\mathbf{A} \rightleftharpoons \mathbf{B}$, Scheme 4) [2,19]. Since, it has been demonstrated that the stereoselectivity of the reaction is closely related to the increase of the percentage of one of the two diastereomers, the control of the steric ligand properties is of paramount importance.

A way to adjust the steric influence of the ligand can be achieved by changing the ligand bite-angle or, in other words, the chelate ring size of the metal-complex. As this parameter increases, the substituents on the ligand are pushed towards the allylic termini and the diastereomeric ratio between $\mathbf{A}$ and $\mathbf{B}$ is therefore modified, influencing in this way the chiral recognition.

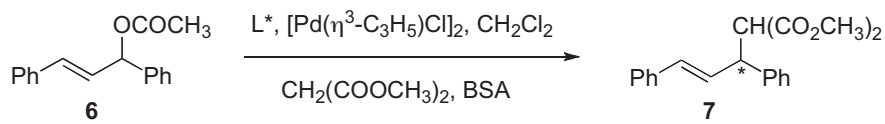

Scheme 3.
On this bases, we examined the iminopyridine $\mathbf{2 c}$ in which an ethylidene unit between the pyridine ring and the imino nitrogen replaces the methylene spacer in $\mathbf{2 a}$. This ligand that by coordination with the metal forms a six-membered chelate ring, namely one more with respect to the related ligand $\mathbf{2 a}$, gave a similar reactive Pd-catalyst, but unfortunately a reduced stereodifferentiating ability affording the product $(S)-7$ with $32 \%$ ee.

Then, as the ring-size control failed, we examined ligand $\mathbf{2 d}$ that differs from 2a by the presence of a methyl group on the 6position of the pyridine ring. This ligand was selected since we demonstrated that, in related oxazolinylpyridine ligands, bulkier substituent than hydrogen on the 6-position of the pyridine ring by increasing the stabilization of the sterically favoured diastereomeric transition state (A or $\mathbf{B}$, Scheme 3 ), gave a much higher enantioselectivity than the related 6-unsubstituted ligand [21]. In other words this substituent that is directed towards the substrate should assist the substituent on the stereocenters of the iminopyridine to improve the stereodifferentiating ability of the ligand. Unfortunately, the use of ligand $\mathbf{2 d}$ was detrimental for both catalytic activity and stereoselectivity, and (S)-7 was obtained with only $9 \%$ ee.

Another modification of the ligand 1a was obtained by introducing two methyl groups on the bridged methylene carbon. The so obtained iminopyridine $\mathbf{2 e}$ would result of increased stiffness with respect to $\mathbf{2 a}$, reducing in this way its conformational mobility in the related Pd-complex. The change in the framework of $\mathbf{2 a}$ had a double effect on the allylic reaction. Thus, ligand $\mathbf{2 e}$ reduced the catalytic activity of the Pd-complex, producing only partial conversion ( $62 \%$ after $72 \mathrm{~h}$ ) of the starting material $\mathbf{6}$, but on the contrary caused an increased enantiomeric excess of the product 7 ( $62 \% \mathrm{ee}$ ). Moreover, the opposite enantiomer $(R)-7$ was surprisingly formed, even though $2 \mathbf{e}$ shares the same stereochemical pattern of the other related ligands $\mathbf{2 a}, \mathbf{c}, \mathbf{d}$.

Since the use of ligands $\mathbf{2 a , c}$ and $\mathbf{2 d}$ afforded (S)-7 as the prevailing enantiomer it is plausible that the reaction proceeds through the same pathway, implicating the attack of the nucleophile on the allylic termini of the same more abundant stereoisomer ( $\mathbf{b}$ in $\mathbf{A}$ or a in $\mathbf{B}$ ). On the other hand, ligand $\mathbf{2 e}$, afforded the opposite enantiomer $(R)-7$, indicating a change of the steric course of the reaction with a possible inversion of the equilibrium between diastereomers 


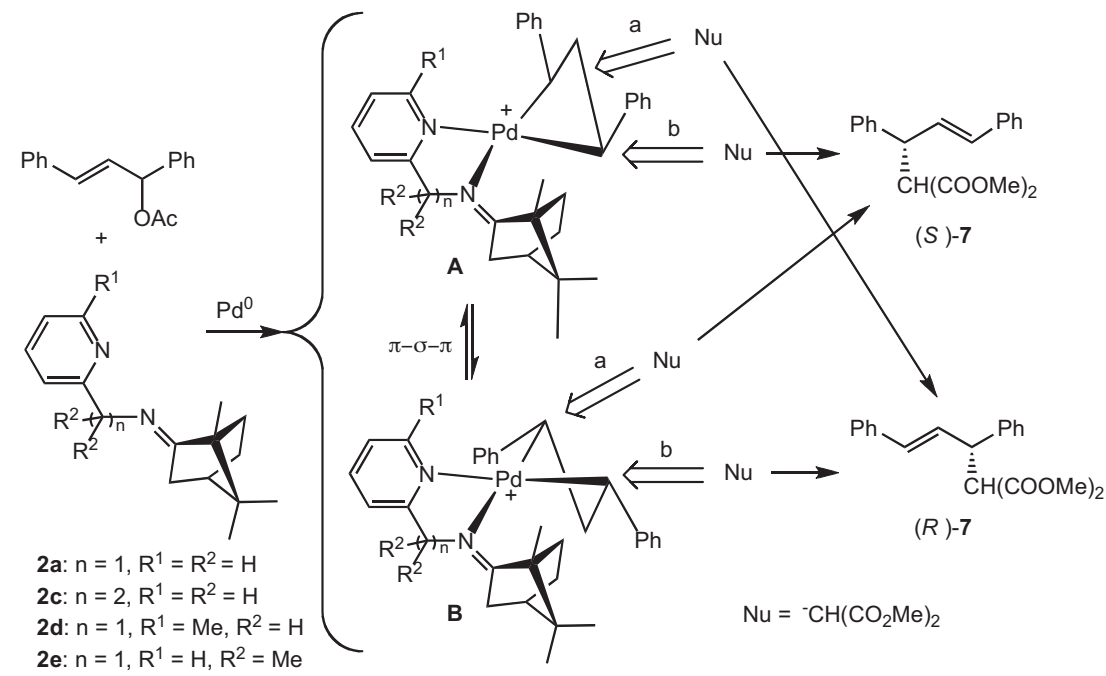

Scheme 4

$\mathbf{A}$ or $\mathbf{B}$, in this way favouring a transition state in which the nucleophile attacks the diastereomers $\mathbf{A}$ or $\mathbf{B}$ via a or b, respectively.

To confirm this trend, the rigid ligand $2 \mathbf{f}$ in which the bridged carbon is enclosed in a benzo-fused ring to the pyridine was prepared. With this ligand, worse results concerning both catalytic activity and enantioselectivity than with $\mathbf{2 e}$ were obtained (entry $7)$. Also in this case the configuration of the prevailing enantiomer was $(R)$.

Next, we turned our attention to the iminopyridines $4 \mathbf{4 a}, \mathbf{c}-\mathbf{g}$ derived from pyridine-2-carboxaldehyde and a variety of chiral amines (Scheme 2). These ligands afforded active Pd-catalysts giving 7 in high yield, but with poor enantioselectivity (Table 1). The best enantioselectivity ( $44 \%$ ee) was obtained with the iminopyridine $\mathbf{4 f}$ based on a camphane skeleton.

We also prepared the iminopyridine 5a from quinoline8-carbaldehyde with (S)-1-phenylethanamine (Scheme 2). This ligand with the same substituent on the imino nitrogen with respect to $\mathbf{4 a}$, but forming with palladium a six-membered chelate ring, gave a better catalytic activity and enantioselectivity than 4a (entry 14 vs 8 , Table 1 ). Encouraged by this result, the iminopyridines 5d,f,g were prepared (Scheme 2). Unfortunately, disappointing results were obtained with these ligands, thus neither the yield nor the stereoselectivity were improved compared to $\mathbf{5 a}$ (Table 1).

\section{Conclusion}

In conclusion, we have developed a new catalytic system for the enantioselective palladium catalyzed allylic substitutions. Thus, a number of new and known iminopyridine-based ligands were prepared and assessed in the enantioselective palladium catalyzed allylic substitution of 1,3-diphenylprop-2-enyl acetate with dimethyl malonate. This kind of ligands afforded the product dimethyl 1,3-diphenylprop-2-enylmalonate in good yields and moderate enantioselectivities (up to $62 \%$ ee). Catalytic activity and enantioselectivity were found to be highly dependent upon the steric properties of the ligands. The best enantioselectivity (62\% ee) was obtained by an iminopyridine based on a camphane skeleton. The application of these iminopyridines in other catalytic enantioselective reactions is currently in progress.

\section{Acknowledgement}

Financial support from the University of Sassari is gratefully acknowledged.

\section{References}

[1] J. Kleimark, P.-O. Norrby, Top. Organomet. Chem. 38 (2012) 65-94

[2] (a) B.M. Trost, D.L. Van Vranken, Chem. Rev. 96 (1996) 395-422; (b) B.M. Trost, M.L. Crawley, Chem. Rev. 103 (2003) 2921-2944; (c) B.M. Trost, J. Org. Chem. 69 (2004) 5813-5837;

(d) Z. Lu, S. Ma, Angew. Chem. 120 (2008) 264-303;

(e) Z. Lu, S. Ma, Angew. Chem. Int. Ed. 47 (2008) 258-297; (f) B.M. Trost, T. Zhang, J.D. Sieber, Chem. Sci. 1 (2010) 427-440.

[3] (a) A. Alexakis, J.E. Bäckvall, N. Krause, O. Pàmies, M. Diéguez, Chem. Rev. 108 (2008) 2796-2823:

(b) C.A. Falciola, A. Alexakis, Eur. J. Org. Chem. (2008) 3765-3780.

[4] (a) G. Helmchen, A. Dahnz, P. Dübon, M. Schelwies, R. Wiehofen, Chem. Commun. (2007) 675-691;

(b) J.F. Hartwig, L.M. Stanley, Acc. Chem. Res. 43 (2010) 1461-1475.

[5] B.M. Trost, J.R. Miller, C.M. Hoffman Jr., J. Am. Chem. Soc. 133 (2011) 8165-8167, and references therein.

[6] (a) T. Graening, H.-G. Schmalz, Angew. Chem. Int. Ed. 42 (2003) 2580-2584; (b) B.M. Trost, M.L. Crawley, Top. Organomet. Chem. 38 (2012) 321-340.

[7] (a) F. Fache, E. Schulz, M.L. Tommasino, M. Lemaire, Chem. Rev. 100 (2000) 2159-2232;

(b) J.-C. Kizirian, Chem. Rev. 108 (2008) 140-205.

[8] H.-L. Kwong, H.-L. Yeung, C.-T. Yeung, W.-S. Lee, C.-S. Lee, W.-L. Wong, Coord. Chem. Rev. 251 (2007) 2188-2222.

[9] G.C. Hargaden, P.J. Guiry, Chem. Rev. 109 (2009) 2505-2550.

[10] G. Chelucci, Coord. Chem. Rev. 257 (2013) 1887-1932.

[11] C.A. Luchaco-Cullis, H. Mizutami, K.E. Murphy, A.H. Hoveyda, Angew. Chem. Int. Ed. 40 (2001) 1456

[12] S. Constant, S. Tortoioli, J. Müller, J. Lacour, Angew. Chem. Int. Ed. 46 (2007) 2082-2085.

[13] X. Hu, H. Dai, C. Bai, H. Chen, Z. Zheng, Tetrahedron: Asymmetry 15 (2004) 1065-1068.

[14] M. Solinas, B. Sechi, S. Baldino, G. Chelucci, J. Mol. Catal. A 378 (2013) 206-212.

[15] (a) G. Blay, E. Climent, I. Fernández, V. Hernández-Olmos, J.R. Pedro, Tetrahedron: Asymmetry 17 (2006) 2046;

(b) G. Blay, E. Climent, I. Fernández, V. Hernández-Olmos, J.R. Pedro, Tetrahedron: Asymmetry 18 (2007) 1603.

[16] (a) G. Chelucci, M. Marchetti, A.V. Malkov, F. Friscourt, M.E. Swarbick, P. Kocovsky, Tetrahedron 67 (2011) 5421-5431;

(b) G. Chelucci, A. Saba, D. Vignola, C. Solinas, Tetrahedron 57 (2001) 1099-1114;

(c) G. Chelucci, G. Deriu, G.A. Pinna, A. Saba, R. Valenti, Tetrahedron: Asymmetry 10 (1999) 3008-3809;

(d) G. Chelucci, G.A. Pinna, A. Saba, Tetrahedron: Asymmetry 8 (1997) 2571-2578;

(e) G. Chelucci, M. Falorni, G. Giacomelli, Tetrahedron: Asymmetry 1 (1990) 843-849.

[17] C. Botteghi, A. Schionato, G. Chelucci, H. Brunner, A. Kürzinger, U. Obermann, J Organomet. Chem. 370 (1989) 17-31

[18] B.M. Trost, D.J. Murphy, Organometallics 4 (1985) 1143-1145.

[19] G. Poli, G. Prestat, F. Liron, C. Kammerer-Pentier, Top. Organomet. Chem. 38 (2012) 1-64.

[20] G. Chelucci, G.A. Pinna, A. Saba, Tetrahedron: Asymmetry 9 (1998) 531-534.

[21] G. Chelucci, S. Medici, A. Saba, Tetrahedron: Asymmetry 8 (1997) 3183-3184. 